\title{
TATE KELOLA PERUSAHAAN, ALIRAN KAS BEBAS DAN MANAJEMEN LABA
}

\author{
FLORENCIA \\ MEINIE SUSANTY \\ Trisakti School of Management, Jl. Kyai Tapa No.20, Kec. Grogol petamburan, Kota Jakarta Barat, Indonesia \\ florenciawijayaa@yahoo.com
}

\begin{abstract}
The purpose of this study is to examine the factors that influence earnings management on non financial companies that listed in Indonesia Stock Exchange. These factors are firm size, audit quality, audit committee, institutional ownership, return on assets, leverage, and free cash flow. Population of this research are non financial companies listed in Indonesia Stock Exchange from 2015-2017. The samples of this study are selected by using purposive sampling method and 558 data are taken. This research used a modified Jones model to calculate discretionary accruals values. This research used multiple regression analysis to determine the relationship between the factors and earnings management. The result of this study shows that return on assets, leverage, and free cash flow have effect on earnings management. On the other hand, firm size, audit quality, audit committee, institutional ownership do not have significant effect on earnings management.
\end{abstract}

Keywords: Earnings management, firm size, audit quality, audit committee, institutional ownership, return on assets, leverage, free cash flow

\begin{abstract}
Abstrak: Tujuan penelitian adalah untuk menguji faktor-faktor yang memengaruhi manajemen laba pada perusahaan non keuangan yang terdaftar di Bursa Efek Indonesia. Faktor-faktor ini terdiri dari ukuran perusahaan, kualitas audit, komite audit, kepemilikan institusional, return on assets, leverage, dan free cash flow. Data populasi dalam penelitian ini adalah perusahaan non keuangan yang terdaftar di Bursa Efek Indonesia selama tahun 20152017. Sampel penelitian ini dipilih dengan menggunakan metode purposive sampling dengan jumlah sampel penelitian sebanyak 558 data. Penelitian ini menggunakan model modified Jones untuk menghitung nilai diskresi akrual. Penelitian ini menggunakan analisis regresi berganda untuk menentukan hubungan antara faktor-faktor yang memengaruhi dengan manajemen laba. Hasil dari penelitian ini menunjukkan bahwa variabel return on assets, leverage, dan free cash flow memiliki pengaruh terhadap manajemen laba, sedangkan variabel ukuran perusahaan, kualitas audit, komite audit, kepemilikan institusional tidak memiliki pengaruh yang signifikan terhadap manajemen laba.
\end{abstract}

Kata kunci: Manajemen laba, ukuran perusahaan, kualitas audit, komite audit, kepemilikan institusional, return on assets, leverage, free cash flow

\section{PENDAHULUAN}

Manajemen laba masih menjadi perhatian bagi kalangan luas hingga saat ini.
Manajemen laba dapat mengurangi reliabilitas laba yang ada pada laporan keuangan karena informasi laba yang dilaporkan dapat menjadi bias. Manajemen laba oportunistik dapat 
mengurangi kepercayaan investor atas informasi laporan keuangan karena informasi tersebut dapat menyesatkan penggunanya. Manajemen laba dapat dipengaruhi oleh beberapa indikator seperti karakteristik perusahaan dan faktor lainnya. Penerapan corporate governance (CG) dalam suatu perusahaan diharapkan dapat mengurangi manajemen laba oportunistik sehingga mampu menghasilkan kinerja keuangan yang berkualitas.

Karakteristik perusahaan salah satunya dapat dilihat dari ukuran besar kecilnya perusahaan. Kualitas audit laporan keuangan diharapkan dapat meningkatkan reliabilitas laba pada laporan keuangan. Laporan keuangan dengan kualitas audit yang tinggi akan menghasilkan laporan yang bebas dari salah saji material sehingga dapat mengurangi asimetri informasi. Implementasi CG juga dapat membantu perusahaan untuk memiliki keunggulan bersaing di masa depan karena kinerja keuangan perusahaan yang baik. Komite audit dan kepemilikan institusional merupakan salah satu mekanisme CG dalam perusahaan. Pembentukan komite audit dan kepemilikan institusional dapat membantu mengawasi jalannya aktivitas operasional perusahaan. Hal ini dikarenakan adanya fungsi pengawasan dari komite audit perusahaan yang bersifat independen dan pengawasan dari pihak institusi.

Karakteristik perusahaan dan implementasi CG yang baik dapat menghasilkan kinerja keuangan yang baik. Kinerja keuangan perusahaan yang baik dapat dilihat dari laporan keuangan yang memiliki tingkat reliabilitas yang tinggi. Indikator-indikator kinerja keuangan perusahaan dapat diukur dari rasio keuangan seperti return on assets (ROA), leverage, dan free cash flow. Indikator-indikator tersebut menggambarkan kondisi keuangan dan kemampuan perusahaan dalam mengelola dananya untuk menghasilkan laba bagi perusahaan.
Investor mengharapkan laporan keuangan perusahaan dapat memberikan informasi yang dapat diandalkan sehingga asimetri informasi dapat diminimalisasi. Asimetri informasi dapat menyebabkan terjadinya konflik kepentingan antara agen dan prinsipal. Konflik kepentingan merupakan faktor yang dapat menyebabkan terjadinya manajemen laba. Prinsipal memberikan wewenang kepada agen untuk mengelola aktivitas perusahaan agar mencapai tujuan yang selaras dengan kepentingan prinsipal. Salah satu tujuan tersebut adalah untuk meningkatkan nilai perusahaan dengan kualitas laba yang baik. Nilai perusahaan yang tinggi menarik investor untuk menanamkan modalnya. Hal ini mendorong agen untuk melakukan manajemen laba agar dapat meningkatkan laba perusahaan sehingga dapat menarik investor dan mempertahankan kreditor dalam suatu perusahaan.

Praktik manajemen laba seringkali dianggap sebagai tindakan yang dapat merugikan berbagai pihak seperti pemegang saham, kreditor, dan lainnya. Laba dalam laporan keuangan yang sudah dimanipulasi dapat menghasilkan informasi yang bias. Informasi yang bias tersebut dapat menyebabkan investor keliru dalam mengambil keputusan dalam berinvestasi. Beberapa kasus praktik manajemen laba yang terjadi di Indonesia dapat dilihat dari kasus PT Indofarma Tbk, PT Bumi Resources Tbk, dan lainnya. Manajemen laba sudah menjadi kasus yang sering terjadi di perusahaan-perusahaan di Indonesia sehingga manajemen laba masih menjadi topik penelitian yang sering diteliti dalam bidang akuntansi hingga saat ini.

$$
\text { Penelitian ini merupakan }
$$
pengembangan dari penelitian Nurdiniah dan Herlina (2015) yang meneliti faktor-faktor yang memengaruhi manajemen laba pada perusahaan manufaktur di Bursa Efek Indonesia (BEI) periode 2011 sampai dengan 2013. Perbedaan penelitian ini dari penelitian 
sebelumnya yaitu (i) penelitian ini menambahkan empat variabel yaitu variabel kualitas audit, komite audit, dan kepemilikan institusional yang berasal dari penelitian Lidiawati dan Asyik (2016) dan variabel free cash flow yang berasal dari penelitian Yogi dan Damayanthi (2016); (ii) periode penelitian ini adalah 2015 sampai dengan 2017; (iii) objek dari penelitian ini adalah perusahaan-perusahaan non keuangan yang terdaftar di BEl. Berdasarkan latar belakang diatas, maka peneliti mengambil judul "Faktor-Faktor yang Memengaruhi Manajemen Laba pada Perusahaan Non Keuangan di BEl".

Rumusan masalah yang akan dikaji dalam penelitian ini adalah apakah terdapat pengaruh antara ukuran perusahaan, kualitas audit, komite audit, kepemilikan institusional, ROA, leverage, dan free cash flow terhadap manajemen laba. Tujuan dari penelitian ini adalah untuk menganalisis pengaruh ukuran perusahaan, kualitas audit, komite audit, kepemilikan institusional, ROA, leverage, dan free cash flow terhadap manajemen laba.

Sistematika penulisan dalam penelitian ini adalah pertama, pendahuluan yang menjelaskan tentang latar belakang penelitian, masalah penelitian, tujuan dan manfaat penelitian, serta sistematika penulisan. Kedua, kerangka teoretis dan pengembangan hipotesis yang menjelaskan kerangka teoretis, hasil penelitian terdahulu, model penelitian, dan pengembangan hipotesis. Ketiga, metode penelitian yang menguraikan tentang bentuk penelitian, objek penelitian, definisi operasional dan pengukuran variabel, teknik pengumpulan data, dan metode analisis data yang digunakan. Keempat, analisis dan pembahasan yang menguraikan tentang gambaran umum sampel (objek penelitian), statistik deskriptif variabel, hasil uji kualitas data dan asumsi klasik, pengujian hipotesis. Kelima, penutup yang menguraikan tentang kesimpulan atas hasil pembahasan penelitian, keterbatasan penelitian, dan rekomendasi untuk penelitian selanjutnya.

\section{Teori Keagenan}

Jensen dan Meckling (1976) mendefinisikan hubungan keagenan sebagai kontrak perjanjian antara prinsipal (pemegang saham) yang melakukan mekanisme pengambilan keputusan dengan campur tangan agen (manajer). Hubungan antara prinsipal dan agen dalam praktiknya sering mengalami konflik perbedaan kepentingan karena masing-masing pihak memiliki kepentingan yang berbeda. Hubungan agensi antara prinsipal dan agen tersebut dapat mendorong terjadinya asimetri informasi.

Gitman (2009) menyatakan bahwa asimetri informasi terjadi ketika agen mendapatkan informasi yang lebih luas dan mendalam mengenai kondisi perusahaan dibandingkan pemegang saham. Lisa (2012) menyatakan tingginya asimetri informasi menyebabkan prinsipal tidak memiliki informasi yang cukup dalam mengawasi tindakan agen. Hal ini dapat memicu terjadinya manajemen laba oportunistik yaitu dengan menggunakan kebijakan-kebijakan tertentu agar manajemen dapat memaksimumkan kesejahteraannya sendiri.

Pearce dan Robinson (2007) menyatakan bahwa konflik kepentingan yang terjadi dalam hubungan agensi dapat mengakibatkan besarnya hasil keputusan yang diambil lebih didasarkan pada kepentingan manajer. Hal ini dapat mendorong terjadinya manajemen laba oportunistik yang dapat mengurangi reliabilitas laporan keuangan.

\section{Contracting Theory}

Godfrey et al. (2010) menyatakan bahwa teori kontrak menggambarkan perusahaan sebagai "nexus" atau hubungan antara pihak pemasok dan konsumen yang terikat oleh kontrak. Hal ini menjelaskan bahwa hubungan agensi memiliki kaitan dengan teori 
kontrak karena adanya hubungan kontrak kerja sama antara prinsipal dan agen.

Kontrak yang ada dalam hubungan agensi diharapkan mampu digunakan sebagai jaminan untuk menyelaraskan kepentingan agen dan prinsipal. Agen diharuskan bertindak sesuai kontrak perjanjian yang telah dibuat dengan prinsipal. Kontrak memiliki fungsi sebagai alat bantu prinsipal dalam mengawasi agen. Selanjutnya dengan adanya kontrak tersebut agen diharapkan mampu memberikan informasi dan hasil keputusan yang membantu meningkatkan kinerja perusahaan.

\section{Manajemen Laba}

Manajemen laba merupakan aktivitas yang dilakukan oleh manajemen dalam bentuk pengaturan laba sesuai dengan hasil yang ingin dicapai (Dewi dan Priyadi 2016). Manajemen diberikan tanggung jawab untuk memaksimalkan laba yang diterima para investor dalam suatu perusahaan. Selanjutnya dalam praktik manajemen juga memiliki motivasi untuk meningkatkan kesejahteraan mereka sendiri (Asrori dan Kiswanto 2014).

Kodriyah dan Fitri (2017) menyatakan bahwa manajemen laba dapat disebabkan oleh adanya tingkat asimetri informasi yang tinggi. Asimetri informasi mendorong terjadinya tindakan manipulasi antara manajemen terhadap pihak investor yang tidak mempunyai akses yang cukup terhadap informasi keuangan perusahaan. Investor yang tidak memiliki akses yang cukup berarti memiliki kelemahan dalam memonitor manajemen. Pengawasan yang kurang dapat memberikan kesempatan bagi manajemen untuk melakukan manajemen laba oportunistik. Hal tersebut bertujuan untuk menyejahterakan kepentingan pribadi agen dibandingkan meningkatkan kinerja perusahaan.

Tindakan manajemen yang memanfaatkan informasi laporan keuangan ini di lain pihak dapat menyebabkan kerugian bagi pemegang saham (Rahmawati et al. 2017).
Kerugian tersebut adalah laporan keuangan yang dipercaya merupakan media antara agen dan prinsipal tidak mampu memberikan informasi yang andal dan relevan. Dasar pengambilan keputusan oleh manajemen tidak mampu menggambarkan kondisi keuangan perusahaan sesuai dengan fakta yang ada (Amertha 2013).

\section{Ukuran Perusahaan dan Manajemen Laba}

Ukuran perusahaan merupakan nilai yang dapat memperlihatkan skala besar kecilnya suatu perusahaan (Launa dan Respati 2014). Mahiswari dan Nugroho (2014) menyatakan ukuran perusahaan dapat dijadikan sebagai alat ukur dalam menentukan banyak atau sedikitnya praktik manajemen laba. Susanto et al. (2019), Manggau (2016) menyatakan bahwa ukuran perusahaan yang lebih besar cenderung tidak melakukan praktik manajemen laba dibandingkan perusahaan kecil. Perusahaan berukuran besar menyediakan informasi yang lebih banyak dan berguna untuk investor. Kondisi perusahaan berukuran besar cenderung lebih diperhatikan oleh masyarakat luas sehingga akan lebih berhati - hati dalam melaporkan keakuratan laporan keuangannya dibandingkan perusahaan kecil yang belum memiliki investor yang banyak.

Berdasarkan penelitian Astari dan Suryanawa (2017), Fitria dan Kurnia (2015) menyatakan bahwa ukuran perusahaan memiliki pengaruh positif terhadap manajemen laba. Hal ini dijelaskan bahwa perusahaan besar mempunyai aktivitas yang lebih rumit dan diharuskan untuk memenuhi ekspektasi investor yang lebih tinggi sehingga dilakukan tindakan manajemen laba untuk mengatasinya. Hasil penelitian tersebut tidak konsisten dengan penelitian Putri dan Machdar (2017), Wiyadi et al. (2015), dan Arifin dan Destriana (2016) yang menyatakan ukuran perusahaan tidak memiliki pengaruh terhadap manajemen laba. Hal ini disebabkan ukuran perusahaan tidak dapat menjadi indikator terjadinya manajemen laba 
karena perusahaan berukuran besar maupun kecil memiliki peluang untuk melakukan manajemen laba (Arifin dan Destriana 2016). Berdasarkan uraian di atas, hipotesis yang diajukan adalah sebagai berikut:

$\mathrm{H}_{1}$ Ukuran perusahaan berpengaruh terhadap manajemen laba

\section{Kualitas Audit dan Manajemen Laba}

DeAngelo (1981) mendefinisikan kualitas audit sebagai kompetensi auditor dalam menemukan salah saji material dalam laporan keuangan dan independensi auditor dalam melaporkan kesalahan tersebut. Kualitas audit yang tinggi diharapkan dapat meminimalisasi asimetri informasi sehingga meningkatkan kepercayaan investor (Christiani dan Nugrahanti 2014). Salah satu indikator pengukuran kualitas audit adalah ukuran KAP yaitu KAP big four dan non big four (Lidiawati dan Asyik 2016).

Berdasarkan penelitian Rahmawati et al. (2017) menyatakan kualitas audit memiliki pengaruh positif terhadap manajemen laba. Hal ini disebabkan auditor yang bekerja di KAP big four lebih berkompeten dan memiliki pengetahuan yang luas dibandingkan auditor KAP non big four. Dengan demikian KAP big four dipercaya memiliki keahlian dan kemampuan lebih mengenai cara mendeteksi adanya manipulasi laporan keuangan. Hasil penelitian ini tidak konsisten dengan penelitian Rahmayanti (2018), Fitria dan Kurnia (2015), Christiani dan Nugrahanti (2014), Agustia (2013), Shiyammurti dan Rachman (2015), dan Lidiawati dan Asyik (2016) yang menyatakan bahwa tidak terdapat pengaruh antara kualitas audit terhadap manajemen laba. KAP tidak difokuskan hanya untuk mendeteksi ada atau tidaknya manajemen laba melainkan adalah cara KAP mengaudit dan menghasilkan laporan keuangan yang berkualitas. Berdasarkan uraian di atas, hipotesis yang diajukan adalah sebagai berikut:

$\mathrm{H}_{2} \quad$ Kualitas audit berpengaruh terhadap manajemen laba

\section{Komite Audit dan Manajemen Laba}

Prastiti dan Meiranto (2013)

menyatakan bahwa independensi adalah salah satu karakteristik utama komite audit yang dapat menambah fungsi pengawasan. Anggota komite audit yang independen akan memberikan laporan keuangan yang lebih berkualitas dengan tidak memihak pada kepentingan tertentu. Lidiawati dan Asyik (2016) menyatakan semakin independen komite audit maka manajemen laba akan semakin rendah. Hal ini disebabkan komite audit semakin meningkatkan fungsi pengawasan terhadap manajemen perusahaan.

Berdasarkan penelitian Prastiti dan Meiranto (2013), Bukit dan Iskandar (2009), Kusumaningtyas (2012), dan Lidiawati dan Asyik (2016) menyatakan bahwa komite audit memiliki pengaruh negatif terhadap praktik manajemen laba. Keberadaan komite audit dapat menurunkan aktivitas manajemen laba dengan pengawasan yang lebih efektif. Karakteristik independensi yang dimiliki komite audit dapat mengakibatkan semakin rendahnya aktivitas manajemen laba di suatu perusahaan. Hasil ini tidak konsisten dengan penelitian Florencea dan Susanto (2019), Guna dan Herawaty (2010), Rahmawati et al. (2017) yang menyatakan komite audit tidak memiliki pengaruh terhadap manajemen laba. Pembentukan komite audit dilakukan hanya untuk memenuhi regulasi yang mensyaratkan perusahaan go public untuk membentuknya (Rahmawati et al. 2017). Berdasarkan uraian di atas, hipotesis yang diajukan adalah sebagai berikut:

$\mathrm{H}_{3}$ Komite audit berpengaruh terhadap manajemen laba

\section{Kepemilikan Institusional dan Manajemen Laba}

Kepemilikan institusional merupakan jumlah saham perusahaan yang dimiliki oleh institusi atau lembaga seperti perusahaan investasi, bank, perusahaan asuransi, dan 
lainnya (Mahariana dan Ramantha 2014). Shleifer dan Vishny (1986) menyatakan semakin besar kepemilikan saham dari investor institusional akan memberikan investor institusional hak pengendalian untuk melakukan aktivitas pengawasan yang lebih tinggi kepada manajemen.

Berdasarkan penelitian Aygun et al. (2014), Asrori dan Kiswanto (2014), dan Utari dan Sari (2016) menyatakan bahwa kepemilikan institusional memiliki pengaruh negatif terhadap manajemen laba. Investor institusional memiliki kemampuan pengawasan serta analisis yang lebih baik dibandingkan investor individual sehingga tidak mudah dimanipulasi oleh manajemen (Utari dan Sari 2016). Hasil ini tidak konsisten dengan penelitian Rahmayanti (2018), Kodriyah (2015), Mahariana dan Ramantha (2014), Fitria dan Kurnia (2015), Kusumaningtyas (2012), dan Tiswiyanti et al. (2012) yang menyatakan kepemilikan institusional tidak memiliki pengaruh terhadap manajemen laba. Hal ini disebabkan karena banyak sedikitnya saham yang dimiliki oleh institusi tidak dapat memengaruhi tingkat terjadinya manajemen laba yang dilakukan oleh manajemen (Tiswiyanti et al. 2012). Berdasarkan uraian di atas, hipotesis yang diajukan adalah sebagai berikut:

$\mathrm{H}_{4}$ Kepemilikan institusional berpengaruh terhadap manajemen laba

\section{Return on assets dan Manajemen Laba}

Firnanti (2017) menyatakan bahwa dalam mengevaluasi kemampuan perusahaan dalam menghasilkan laba dapat dilihat dari segi aset, penjualan, dan investasi. Yuliana dan Trisnawati (2015) menyatakan bahwa semakin besar ROA menggambarkan semakin efisien laba yang mampu dihasilkan oleh manajemen dalam mengelola jumlah aset yang dimiliki perusahaan. Selanjutnya motivasi agen yang oportunistik dalam mendapatkan bonus yang lebih besar mendorongnya untuk melakukan manajemen laba dengan meningkatkan laba agar ROA meningkat.

Berdasarkan penelitian Penelitian Guna dan Herawaty (2010), Firnanti (2017) menyatakan bahwa profitabilitas yang diproksikan dengan ROA memiliki pengaruh positif terhadap manajemen laba. Perusahaan yang memiliki tingkat profitabilitas tinggi memberikan informasi bagi manajer untuk mengukur adanya kemampuan perusahaan dalam menghasilkan laba. Laba perusahaan memotivasi manajemen untuk melakukan praktik manajemen laba karena laba tersebut ingin digunakan untuk menyejahterakan kepentingan manajemen itu sendiri (Firnanti 2017). Hasil ini tidak sejalan dengan penelitian Susanto (2013) dan Wiyadi et al. (2015) yang menyatakan bahwa ROA tidak memiliki pengaruh terhadap manajemen laba. Hal ini disebabkan para investor menyadari bahwa laba yang tercantum dalam laporan keuangan masih dapat dipermainkan oleh pihak manajemen (Susanto 2013). Berdasarkan uraian di atas, hipotesis yang diajukan adalah sebagai berikut: $\mathrm{H}_{5}$ ROA berpengaruh terhadap manajemen laba

\section{Leverage dan Manajemen Laba}

Susanto, dan Agness (2019), Yudy dan Susanto (2018), Upayarto (2013) menyatakan bahwa leverage disebabkan oleh adanya usaha penambahan kas untuk membantu aktivitas operasional perusahaan. Semakin tinggi leverage berarti meningkatkan risiko dimana kemampuan perusahaan untuk melunasi kewajiban kepada kreditor semakin rendah. Hal ini mengakibatkan manajer seringkali memilih metode akuntansi yang dapat menaikkan angka laba agar keuangan perusahaan tetap terlihat baik walaupun adanya leverage yang tinggi.

Berdasarkan penelitian Agustia (2013) dan Utari dan Sari (2016) menyatakan bahwa leverage memiliki pengaruh positif terhadap manajemen laba. Leverage yang tinggi menggambarkan perusahaan terancam berisiko gagal bayar. Perusahaan akan mendorong 
manajemen untuk melakukan manajemen laba dengan tujuan untuk mempertahankan kinerja baiknya di mata investor. Hasil penelitian ini tidak sejalan dengan penelitian Nahar dan Erawati (2017), Wiyadi et al. (2015), dan Kodriyah dan Fitri (2017) yang menyatakan bahwa leverage tidak memiliki pengaruh signifikan terhadap manajemen laba. Manajemen laba tidak dapat dijadikan alat untuk menghindari pelunasan utang karena kewajiban tersebut tetap harus dibayar dan tidak dapat dihindari (Kodriyah dan Fitri 2017). Berdasarkan uraian di atas, hipotesis yang diajukan adalah sebagai berikut:

$\mathrm{H}_{6}$ Leverage berpengaruh terhadap manajemen laba

\section{Free cash flow dan Manajemen Laba}

Free cash flow adalah kas perusahaan yang tidak digunakan untuk modal kerja atau investasi aset tetap sehingga bebas dibagikan kepada pemegang saham atau kreditur (Ross et al. 2010). Yogi dan Damayanthi (2016) menyatakan arus kas berlebih yang seharusnya disalurkan sebagai dividen, dimanfaatkan oleh manajer untuk berinvestasi. Manajer mengharapkan perusahaan melihat kinerjanya meskipun hasil investasi tersebut tidak selalu menghasilkan keuntungan atau laba bagi perusahaan.

Berdasarkan penelitian Kodriyah dan Susanto et al. (2017), Fitri (2017), Bukit dan Iskandar (2009), dan Dewi dan Priyadi (2016) menyatakan bahwa free cash flow memiliki pengaruh positif terhadap manajemen laba. Manajemen cenderung menggunakan arus kas berlebih yang ada untuk berinvestasi meski investasi tersebut menghasilkan NPV negatif (Dewi dan Priyadi 2016). Hasil ini tidak konsisten dengan penelitian Agustia (2013) dan Yogi dan Damayanthi (2016) yang menyatakan free cash flow memiliki pengaruh negatif terhadap manajemen laba. Arus kas bebas yang tinggi menunjukkan adanya kemampuan perusahaan dalam membagikan dividen sehingga perusahaan tidak perlu melakukan manajemen laba untuk dapat meningkatkan harga sahamnya (Yogi dan Damayanthi 2016). Berdasarkan uraian di atas, hipotesis yang diajukan adalah sebagai berikut:

$\mathrm{H}_{7}$ Free cash flow berpengaruh terhadap manajemen laba

\section{METODE PENELITIAN}

Metode pemilihan sampel yang digunakan adalah purposive sampling, yaitu metode pengambilan sampel berdasarkan kriteria tertentu yang digunakan oleh peneliti (Sekaran dan Bougie 2016). Kriteria perusahaan yang dapat dijadikan sampel adalah sebagai berikut:

1. Perusahaan non keuangan yang terdaftar di BEl selama periode 2015 sampai dengan 2017.

2. Perusahaan yang menerbitkan laporan keuangan yang memiliki akhir periode tahun buku 31 Desember.

3. Perusahaan yang menggunakan mata uang rupiah dalam laporan keuangannya.

4. Perusahaan yang memperoleh laba positif selama periode 2015 sampai dengan 2017.

5. Perusahaan yang memiliki kepemilikan institusional. 
Tabel 1 Prosedur Pemilihan Sampel

\begin{tabular}{lcc}
\hline \multicolumn{1}{c}{ Keterangan } & Perusahaan & Data \\
\hline $\begin{array}{l}\text { Perusahaan non keuangan yang terdaftar di BEl selama periode } 2015 \\
\text { sampai dengan 2017 }\end{array}$ & 410 & 1230 \\
$\begin{array}{l}\text { Perusahaan yang tidak menerbitkan laporan keuangan yang memiliki } \\
\text { akhir periode tahun buku 31 Desember }\end{array}$ & $(8)$ & $(24)$ \\
$\begin{array}{l}\text { Perusahaan yang tidak menggunakan mata uang rupiah dalam laporan } \\
\text { keuangannya }\end{array}$ & $(78)$ & $(234)$ \\
$\begin{array}{l}\text { Perusahaan yang tidak memperoleh laba positif selama periode 2015 } \\
\text { sampai dengan 2017 }\end{array}$ & $(133)$ & $(399)$ \\
Perusahaan yang tidak memiliki kepemilikan institusional & $(5)$ & $(15)$ \\
\hline Jumlah sampel penelitian & 186 & 558 \\
\hline
\end{tabular}

Sumber: Data diperoleh dari www.idx.co.id

Manajemen laba adalah suatu perilaku manajemen perusahaan yang mengatur laba dengan cara meningkatkan atau mengurangi laba sesuai dengan tujuan (Dewi dan Priyadi 2016). Manajemen laba menggunakan skala rasio dan model modifikasi Jones (Susanto 2017, Nurdiniah dan Herlina 2015) yang dilambangkan dengan EM. Variabel manajemen laba diukur dengan menggunakan nilai absolut dari Discretionary Accruals (DA) yang dilakukan dengan langkah sebagai berikut:

Langkah Pertama

Langkah Kedua

$$
T A C_{i t}=N I_{i t}-C F O_{i t}
$$

$\frac{T A C_{t, i}}{T A_{t-1}}=\alpha_{1}\left(\frac{1}{T A_{i, t-1}}\right)+\alpha_{2}\left(\frac{\Delta S A L E S-\Delta R E C}{T A_{i, t-1}}\right)+\alpha_{3}\left(\frac{P P E}{T A_{t-1}}\right)$
$+\varepsilon$

Langkah Ketiga

$N D A_{i, t}=\alpha_{1}\left(\frac{1}{T A_{i, t-1}}\right)+\alpha_{2}\left(\frac{\Delta S A L E S-\Delta R E C}{T A_{i, t-1}}\right)+\alpha_{3}\left(\frac{P P E}{T A_{t-1}}\right)$

Langkah Keempat

$$
D A_{i t}=\frac{T A C_{t, i}}{T A_{t-1}}-N D A_{i t}
$$

Ukuran perusahaan adalah skala pengukuran besar kecilnya suatu perusahaan (Putri dan Titik 2014). Ukuran perusahaan dihitung menggunakan skala rasio yang dilambangkan dengan SIZE. Penelitian
Nurdiniah dan Herlina (2015) merumuskan ukuran perusahaan sebagai berikut:

Company size $(\mathrm{SIZE})=\ln$ (Total Assets)

Kualitas audit adalah kemampuan auditor dalam mendeteksi salah saji material (kompetensi auditor) dan kebijaksanaan auditor dalam melaporkan kesalahan penyajian laporan keuangan (independensi auditor) (De Angelo 1981). Kualitas audit perusahaan menggunakan skala nominal yang dilambangkan dengan KAP. Kualitas audit perusahaan dalam penelitian ini menggunakan variabel dummy (Lidiawati dan Asyik 2016) dengan pengukuran sebagai berikut:

$1=$ Perusahaan diaudit KAP big four

$0=$ Perusahaan diaudit KAP non big four

Komite audit biasanya terdiri dari tiga sampai lima anggota direksi yang bukan merupakan bagian dari manajemen perusahaan yang ikut dalam membantu pengawasan aktivitas manajemen (Arens et al. 2014). Variabel komite audit dihitung dengan menggunakan skala rasio dan dilambangkan dengan KMA. Penelitian Lidiawati dan Asyik (2016) mengukur variabel komite audit dengan menggunakan rumus:

$\mathrm{KMA}=$ (Jumlah anggota komite audit dari luar)/(Jumlah anggota komite audit) 
Kepemilikan institusional merupakan jumlah kepemilikan saham yang dimiliki institusi seperti bank, perusahaan asuransi, PT, perusahaan investasi, dana pensiun, yayasan, PT, dan institusi lainnya (Novaridha 2017). Kepemilikan institusional menggunakan skala rasio dan dilambangkan dengan $\mathrm{KI}$. Penelitian Lidiawati dan Asyik (2016) menggunakan rumus sebagai berikut:

$\mathrm{KI}=$ (Jumlah saham investor institusi)/(Jumlah modal saham)

ROA merupakan salah satu alat ukur kemampuan manajemen dalam menghasilkan sejumlah laba secara keseluruhan dengan menggunakan perhitungan aset yang dimiliki oleh perusahaan (Yuliana dan Trisnawati 2015). ROA dalam penelitian ini dihitung dengan menggunakan skala rasio. Rumus variabel ROA dalam penelitian ini mengacu pada jurnal Firnanti (2017) yang dapat dijelaskan sebagai berikut:

ROA $=($ Laba Bersih Setelah Pajak)/(Total Aset)
Leverage dapat digunakan untuk mengukur besarnya nilai aset yang dibiayai oleh utang perusahaan (Naftalia dan Marsono 2013). Skala yang digunakan adalah skala rasio dan dilambangkan dengan LEV. Penelitian Nurdiniah dan Herlina (2015) menjelaskan leverage dengan menggunakan rumus sebagai berikut:

$\mathrm{LEV}=($ Total Debt)/(Total Assets)

Free cash flow merupakan kas perusahaan yang tidak digunakan untuk working capital atau investasi aset tetap sehingga dapat didistribusikan sebagai dividen kepada pemegang saham (Ross et al. 2010). Free cash flow diukur menggunakan skala rasio dan dilambangkan dengan FCF. Rumus penelitian Yogi dan Damayanthi (2016) mengukur variabel free cash flow sebagai berikut:

$\mathrm{FCF}=(\mathrm{CFO}-\mathrm{CFI}) /($ Total Aset $)$

$\mathrm{CFO}=$ Arus kas operasi,

$\mathrm{CFI}=$ Arus kas investasi

\section{HASIL PENELITIAN}

Hasil uji statistik deskriptif dan hipotesis dapat dilihat pada tabel berikut:

Tabel 2 Statistik Deskriptif

\begin{tabular}{lllll}
\hline Variabel & Minimum & Maksimum & Rerata & Deviasi Standar \\
\hline EM & 0,000023 & 0,704416 & 0,062159 & 0,072134 \\
SIZE & 24,568314 & 33,320184 & 28,890870 & 1,543002 \\
KAP & 0,0 & 1,0 & 0,414 & 0,4930 \\
KMA & 0,333333 & 1,000000 & 0,975060 & 0,103247 \\
KI & 0,051432 & 0,994297 & 0,660312 & 0,189071 \\
ROA & 0,000180 & 0,526704 & 0,072013 & 0,072147 \\
LEV & 0,007623 & 0,933230 & 0,431816 & 0,184570 \\
FCF & $-0,443804$ & 0,532489 & 0,015417 & 0,107338 \\
\hline
\end{tabular}


Tabel 3 Uji Hipotesis

\begin{tabular}{lll}
\hline Variabel & B & Sig. \\
\hline Konstanta & 0,135 & 0,068 \\
SIZE & $-0,004$ & 0,064 \\
KAP & 0,003 & 0,653 \\
KMA & 0,021 & 0,464 \\
KI & $-0,026$ & 0,112 \\
ROA & 0,351 & 0,000 \\
LEV & 0,044 & 0,009 \\
FCF & $-0,160$ & 0,000 \\
\hline
\end{tabular}

Nilai signifikansi ukuran perusahaan adalah sebesar 0,064 maka dapat disimpulkan bahwa $\mathrm{H}_{1}$ tidak dapat diterima. Hal ini menunjukkan bahwa ukuran perusahaan tidak memiliki pengaruh terhadap manajemen laba. Hasil penelitian ini sejalan dengan penelitian Arifin dan Destriana (2016), Agustia dan Suryani (2018), Putri dan Machdar (2017), dan Wiyadi et al. (2015). Hal ini dikarenakan ukuran perusahaan tidak dapat dijadikan alat ukur terjadinya praktik manajemen laba karena perusahaan berskala besar atau kecil memiliki peluang untuk melakukannya (Arifin dan Destriana 2016).

Nilai signifikansi kualitas audit adalah sebesar 0,653 maka dapat disimpulkan bahwa $\mathrm{H}_{2}$ tidak dapat diterima. Hal ini menunjukkan bahwa variabel kualitas audit yang diukur dengan KAP big four dan non big four tidak memiliki pengaruh terhadap manajemen laba. Hasil penelitian ini sejalan dengan penelitian Rahmayanti (2018), Lidiawati dan Asyik (2016) Fitria dan Kurnia (2015), Christiani dan Nugrahanti (2014), Agustia (2013), dan Shiyammurti dan Rachman (2015). Teori agensi menyatakan audit eksternal merupakan salah satu biaya pengawasan yang dikeluarkan oleh perusahaan dalam menjamin bebas salah saji material dan laporan keuangan mencerminkan nilai yang sesungguhnya.

Auditor eksternal bertanggung jawab sebagai media antara perusahaan dengan pihak luar dalam memberikan informasi terkait laporan keuangan. Hal ini bertujuan untuk mengurangi terjadinya asimetri informasi. Upaya dalam mengatasi manajemen laba melalui kualitas audit yang diukur dengan ukuran KAP berupa KAP big four dan non big four dalam praktiknya belum mampu menekan manajemen laba. Hal ini dikarenakan fungsi utama KAP tidak difokuskan untuk mendeteksi manajemen laba melainkan adalah keahlian KAP dalam menilai kewajaran laporan keuangan sehingga menghasilkan laporan yang dapat diandalkan (Lidiawati dan Asyik 2016).

Nilai signifikansi komite audit adalah sebesar 0,464 maka dapat disimpulkan bahwa $\mathrm{H}_{3}$ tidak dapat diterima. Hal ini menunjukkan bahwa komite audit tidak memiliki pengaruh terhadap manajemen laba. Hasil penelitian ini sejalan dengan penelitian Guna dan Herawaty (2010), Rahmawati et al. (2017). Komite audit merupakan mekanisme CG berupa bonding cost yang bertujuan untuk mengatasi masalah agensi. Karakteristik independensi yang dimiliki komite audit dalam praktiknya tidak menjamin dapat mengurangi terjadinya manajemen laba. Hal ini dikarenakan komite audit dibentuk hanya untuk memenuhi regulasi yang mengharuskan perusahaan yang telah publik untuk membentuk komite audit (Rahmawati et al. 2017). Dengan demikian keberadaan komite audit dalam suatu perusahaan masih belum dapat mengawasi praktik manajemen laba.

Nilai signifikansi kepemilikan institusional adalah sebesar 0,112 maka dapat 
disimpulkan bahwa $\mathrm{H}_{4}$ tidak dapat diterima. $\mathrm{Hal}$ ini menunjukkan bahwa variabel kepemilikan institusional tidak memiliki pengaruh terhadap manajemen laba. Hasil penelitian ini sejalan dengan penelitian Tiswiyanti et al. (2012), Rahmayanti (2018), Kodriyah (2015), Mahariana dan Ramantha (2014), Fitria dan Kurnia (2015), Kusumaningtyas (2012). Hal ini disebabkan karena fokus utama investor institusional hanya untuk memperoleh laba saat ini (current earnings) dan kurang memiliki kemampuan dalam mengawasi tindakan manajemen laba. Selanjutnya investor institusional tidak memiliki peran sebagai sophisticated investors yang dapat mendisiplinkan manajemen agar berfokus dalam meningkatkan nilai perusahaan (Agustia 2013).

Nilai signifikansi ROA adalah sebesar 0,000 maka dapat disimpulkan bahwa $\mathrm{H}_{5}$ dapat diterima. Hal ini menunjukkan bahwa variabel ROA memiliki pengaruh terhadap manajemen laba dengan arah yang positif. Hasil penelitian ini sejalan dengan penelitian Firnanti (2017) dan Guna dan Herawaty (2010). ROA dapat digunakan sebagai indikator kemampuan agen dalam menghasilkan laba bagi perusahaan. Semakin besar nilai ROA menunjukkan semakin meningkatnya laba yang dapat dihasilkan agen dalam menggunakan aset perusahaan (Yuliana dan Trisnawati 2015). Hal ini memotivasi agen untuk meningkatkan laba agar ROA perusahaan meningkat sehingga kinerja agen dapat terlihat baik di mata prinsipal.

Nilai signifikansi leverage adalah sebesar 0,009 maka dapat disimpulkan bahwa $\mathrm{H}_{6}$ dapat diterima. Hal ini menunjukkan bahwa variabel leverage memiliki pengaruh terhadap manajemen laba dengan arah yang positif. Hasil penelitian ini sejalan dengan penelitian Agustia (2013), Utari dan Sari (2016), Firnanti (2017), Upayarto (2013). Perusahaan berupaya menambah jumlah kas perusahaan dengan meminjam kepada kreditor (Upayarto 2013). Peminjaman tersebut harus berdasarkan kontrak perjanjian yang telah disetujui kedua belah pihak. Utari dan Sari (2016) menyatakan semakin meningkatnya leverage perusahaan akan meningkatkan risiko gagal bayar perusahaan tersebut. Perusahaan akan memanfaatkan manajemen laba dengan meningkatkan laba agar mampu mempertahankan kualitas laporan keuangannya. Hal ini menyebabkan kemampuan perusahaan dalam membayar utang tetap dipercaya oleh kreditor sehingga diberikan peminjaman sumber dana yang dibutuhkan perusahaan.

Nilai signifikansi free cash flow adalah sebesar 0,000 maka dapat disimpulkan bahwa $\mathrm{H}_{7}$ dapat diterima. Hal ini menunjukkan bahwa variabel free cash flow memiliki pengaruh terhadap manajemen laba dengan arah yang negatif. Hasil penelitian ini sejalan dengan penelitian Suwanti dan Wahidahwati (2017), Agustia (2013). Besarnya nilai free cash flow menunjukkan bahwa kondisi perusahaan berjalan stabil. Kelebihan kas yang diberikan kepada investor dalam bentuk dividen mendorong meningkatnya harga saham tanpa harus dilakukannya praktik manajemen laba (Yogi dan Damayanthi 2016). Perusahaan yang mampu membagikan dividen kepada investor secara rutin mengindikasikan bahwa agen telah memberikan kinerja baiknya dalam mengelola keuangan perusahaan sehingga praktik manajemen laba tidak perlu dilakukan.

\section{PENUTUP}

Hasil pengujian yang diperoleh dalam penelitian ini dapat disimpulkan bahwa return on assets, leverage, dan free cash flow memiliki pengaruh terhadap manajemen laba. Sedangkan ukuran perusahaan, kualitas audit, komite audit, kepemilikan institusional tidak memiliki pengaruh terhadap manajemen laba. Penelitian ini hanya menggunakan periode penelitian selama 2015 sampai dengan 2017 sehingga hasilnya belum dapat diambil kesimpulan secara menyeluruh. Penelitian ini 
hanya menguji tujuh variabel independen dari indikator karakteristik perusahaan, mekanisme CG, dan kinerja keuangan dimana masih terdapat banyak variabel independen lain yang dapat memengaruhi manajemen laba. Periode penelitian yang dilakukan selanjutnya dapat menggunakan periode yang lebih panjang yaitu sebelum 2015 atau setelah 2017 sehingga dapat diambil kesimpulan yang lebih menyeluruh. Penelitian selanjutnya diharapkan dapat menambah jumlah variabel independen seperti indikator karakteristik perusahaan seperti umur perusahaan dan lain-lain; mekanisme CG seperti kepemilikan manajerial dan lain-lain; indikator kinerja keuangan seperti ROE dan lainlain.

\section{REFERENSI:}

Agustia, Dian. 2013. Pengaruh Faktor Good corporate governance, Free cash flow, dan Leverage terhadap Manajemen Laba. Jurnal Akuntansi dan Keuangan, 15(1).

Agustia, Yofi Prima dan Elly Suryani. 2018. Pengaruh arifUkuran Perusahaan, Umur Perusahaan, Leverage, dan Profitabilitas terhadap Manajemen Laba (Studi pada Perusahaan Pertambangan yang terdaftar di Bursa Efek Indonesia Periode 2014-2016). Jurnal Aset (Akuntansi Riset), 10(1), 63-74.

Amertha, Indra Satya Prasavita. 2013. Pengaruh Return on Asset pada Praktik Manajemen Laba dengan Moderasi Corporate Governance. E-Jurnal Akuntansi Universitas Udayana, 4(2), 373-387.

Arens, Alvin A., Randal J. Elder, Mark S. Beasley. 2014. Auditing and Assurance Service: An Integrated Approach, $7^{\text {th }}$ Edition. England: Pearson Education Limited.

Arifin, Lavenia dan Nicken Destriana. 2016. Pengaruh Firm Size, Corporate Governance, dan Karakteristik Perusahaan terhadap Manajemen Laba. Jurnal Bisnis dan Akuntansi, 18(1), 84-93.

Asrori, Bowo Sumanto dan Kiswanto. 2014. Pengaruh Kepemilikan Institusional dan Ukuran Dewan Komisaris terhadap Manajemen Laba. Accounting Analysis Journal, 3(1), 44-52.

Astari, Anak Agung Mas Ratih dan I Ketut Suryanawa. 2017. Faktor-Faktor yang Mempengaruhi Manajemen Laba. E-Jurnal Akuntansi Universitas Udayana. 20(1), 290-319.

Aygun, Mehmet, Suleyman Ic, dan Mustafa Sayim. 2014. The Effect of Corporate Ownership Structure and Board Size on Earnings Management: Evidence from Turkey. International Journal of Business and Management, 9(12), 123-132.

Bukit, Rina BR. dan Takiah Mohd Iskandar. 2009. Surplus Free cash flow, Earnings Management, and Audit Quality. Int. Journal of Economics and Management. 3(1), 204-223.

Christiani, Ingrid dan Yeterina Widi Nugrahanti. 2014. Pengaruh Kualitas Audit terhadap Manajemen Laba. Jurnal Akuntansi dan Keuangan, 16(1), 52-62.

DeAngelo, Linda Elizabeth. 1981. Auditor Size and Audit Quality. Journal of Accounting and Economics, 3(3), 183199.

Dewi, Rina Pusvita dan Maswar Patuh Priyadi. 2016. Pengaruh Free cash flow, Kinerja Keuangan terhadap Earnings Management Dimoderasi Corporate Governance. Jurnal IImu dan Riset Akuntansi, 5(2), 1-24.

Firnanti, Friska. 2017. Pengaruh Corporate Governance dan Faktor-faktor Lainnya terhadap Manajemen Laba. Jurnal Bisnis dan Akuntansi, 19(1), 66-80.

Fitria, Miftahul dan Kurnia. 2015. Pengaruh Struktur Kepemilikan, Ukuran Perusahaan dan Kualitas Audit terhadap Manajemen Laba. Jurnal IImu dan Riset Akuntansi, 4(6), 1-15.

Florencea, Novia dan Susanto, Yulius Kurnia. 2019. Audit Committee: Woman, Experience, Education on Earnings Management. Proceedings of the 5th Annual International Conference on Accounting Research (AICAR 2018). https://doi.org/10.2991/aicar-18.2019.5

Gitman, Lawrence J. 2009. Principles of Managerial Finance. Boston: Pearson Education.

Godfrey, Jayne, Allan Hodgson, Ann Tarca, Jane Hamilton, Scott Holmes. 2010. Accounting Theory $7^{\text {th }}$ Edition. New York: John Wiley \& Sons. 
Guna, Welvin I dan Arleen Herawaty. 2010. Pengaruh Mekanisme Good corporate governance, Independensi Auditor, Kualitas Audit dan Faktor Lainnya terhadap Manajemen Laba. Jurnal Bisnis dan Akuntansi, 12(1), 53-68.

Jensen, Michael C. dan William H. Meckling. 1976. Theory of the Firm: Managerial Behavior, Agency Costs, and Ownership Structure. Journal of Financial Economics, 3(4), 305-360.

Kodriyah. 2015. Pengaruh Kepemilikan Institusional, Ukuran Perusahaan, Leverage, dan Good corporate governance terhadap Manajemen Laba (Studi Empiris pada Perusahaan Manufaktur yang Terdaftar di BEI 2009-2012). Jurnal Akuntansi, 2(1), 61-71.

Kodriyah dan Anisah Fitri. 2017. Pengaruh Free cash flow dan Leverage terhadap Manajemen Laba pada Perusahaan Manufaktur di BEl. Jurnal Akuntansi, 3(2), 64-76.

Kusumaningtyas, Metta. 2012. Pengaruh Independensi Komite Audit dan Kepemilikan Institusional terhadap Manajemen Laba. Prestasi, 9(1), 41-61.

Launa, Elvia dan Novita Weningtyas Respati. 2014. Pengaruh Mekanisme Corporate Governance dan Ukuran Perusahaan terhadap Manajemen Laba. Jurnal Reviu Akuntansi dan Keuangan, 4(1), 507-524.

Lidiawati, Novi dan Nur Fadjrih Asyik. 2016. Pengaruh Kualitas Audit, Komite Audit, Kepemilikan Institusional, Ukuran Perusahaan terhadap Manajemen Laba. Jurnal IImu dan Riset Akuntansi, 5(5), 1-19.

Lisa, Oyong. 2012. Asimetri Informasi dan Manajemen Laba: Suatu Tinjauan dalam Hubungan Keagenan. Jurnal WIGA, 2(1), $42-49$.

Mahariana, I Dewa Gede Pingga dan I Wayan Ramantha. 2014. Pengaruh Kepemilikan Manajerial dan Kepemilikan Institusional pada Manajemen Laba pada Perusahaan Manufaktur di Bursa Efek Indonesia. E-Jurnal Akuntansi Universitas Udayana, 7(2), 519-528.

Mahiswari, Raras dan Paskah Ika Nugroho. 2014. Pengaruh Mekanisme Corporate Governance, Ukuran Perusahaan, dan Leverage terhadap Manajemen Laba dan Kriteria Keuangan. Jurnal Ekonomi dan Bisnis, 17(1), 1-20.

Manggau, Anastasia Wenny. 2016. Pengaruh Asimetri dan Ukuran Perusahaan terhadap Manajemen Laba pada Perusahaan Pertambangan yang Terdapat di Bursa Efek Indonesia. Jurnal Ekonomi dan Keuangan, 13(2), 103-114.

Naftalia, Veliandina Chivan dan Marsono. 2013. Pengaruh Leverage terhadap Manajemen Laba dengan Corporate Governance sebagai Variabel Pemoderasi. Diponegoro Journal of Accounting, 2(3), 1-8.

Nahar, Mahfudzotun dan Taguh Erawati. 2017. Pengaruh NPM, FDR, Komite Audit, Pertumbuhan Usaha, Leverage, dan Size terhadap Manajemen Laba. Akuntansi Dewantara, 1(1), 63-74.

Novaridha, Ira Astria. 2017. Pengaruh Kepemilikan Institusional, Ukuran Perusahaan dan Profitabilitas terhadap Elemen-Elemen Integrated Reporting (Studi pada Perusahaan Non-Keuangan yang Listing di BEl Tahun 2015). JOM Fekon, 4(1), 3399-3411.

Nurdiniah, Dade dan Linda Herlina. 2015. Analysis of Factors Affecting The Motivation of Earnings Management in Manufacturing Listed in Indonesia Stock Exchange. Research Journal of Finance and Accounting, 6(3), 100-107.

Pearce, John A. dan Richard B. Robinson. 2007. Manajemen Strategis- Formulasi, Implementasi, dan Pengendalian. Jakarta: Salemba Empat.

Prastiti, Anindyah dan Wahyu Meiranto. 2013. Pengaruh Karakteristik Dewan Komisaris dan Komite Audit terhadap Manajemen Laba. Diponegoro Journal of Accounting, 2(4), 1-12.

Putri, Mauliridiyah Sevilia dan Farida Titik. 2014. Pengaruh Kepemilikan Manajerial, Leverage, dan Ukuran Perusahaan terhadap Manajemen Laba pada Perusahaan Food and Beverage (Studi pada Perusahaan Food and Beverage yang Terdaftar di Bursa Efek Indonesia tahun 2008-2013). E-Proceeding of Management, 1(3), 238-254.

Putri, Firstian Andrea dan Nera Marinda Machdar. 2017. Pengaruh Asimetri Informasi Arus Kas Bebas dan Ukuran Perusahaan terhadap Manajemen Laba. Kalbisocio Jurnal Bisnis dan Komunikasi, 4(1). 
Rahmawati, Melai, Siti Noor Khikmah, dan Veni Soraya Dewi. 2017. Pengaruh Kualitas Auditor dan Corporate Governance terhadap Manajemen Laba (Studi Empiris pada Perusahaan Manufaktur yang Terdaftar di Bursa Efek Indonesia Periode 2011-2016). The $6^{\text {th }}$ University Research Colloquium 2017, 459-474.

Rahmayanti, Elvi. 2018. Analysis of Corporate Governance Influence on Earnings Management and Earnings Management Differential Test (Empirical Study on Manufacturing Companies Listed on Indonesia Stock Exchange for The Period of 2012-2016). Bilancia, 2(1).

Ross, Stephen A., Randolph W. Westerfield, Bradford D. Jordan. 2010. Fundamentals of Corporate Finance, $9^{\text {th }}$ Edition. United States of America: McGraw-Hill Irwin.

Sekaran, Uma dan Roger Bougie. 2016. Research Methods for Busines: A Skill Building Approach, $7^{\text {th }}$ Edition. United Kingdom: John Wiley \& Sons Ltd.

Shiyammurti, Nastiti Rizky dan Andry Arifian Rachman. 2015. Pengaruh Struktur Kepemilikan dan Praktik Good corporate governance terhadap Manajemen Laba (Studi Kasus pada Perusahaan Manufaktur Sub Sektor Farmasi yang Terdaftar di Bursa Efek Indonesia Tahun 2010-2013). E-Proceeding of Management, 2(1), 433-443.

Shleifer, Andrei dan Robert W. Vishny. 1986. Large Shareholders and Corporate Control. Journal of Political Economy, 94(3), 461-488.

Susanto, Yulius Kurnia. 2013. The Effect of Corporate Governance Mechanism on Earnings Management Practice (Case Study on Indonesia Manufacturing Industry). Jurnal Bisnis dan Akuntansi, 15(2), 157-167.

Susanto, Yulius Kurnia. 2017. Accrual Earnings Management, Real Earnings Management, Firm Value International Journal of Business, Economics and Law, 14(1), 1-6.

Susanto, Y. Kurnia., Arya Pradipta, dan Indra A. Djashan. 2017. Free Cash Flow and Earnings Management: Board of Commissioner, Board Independence and Audit Quality. Corporate Ownership and Control, 14 (4-1), 284288.

Susanto, Yulius Kurnia, dan V. Agness. 2019. Firm Characteristics, Financial Leverage, Corporate Governance, and Earnings Management in Indonesia. Proceedings of the 5th Sebelas Maret International Conference on Business, Economics and Social Sciences (SMICBES 2018), Bali, Indonesia.

Susanto, Yulius Kurnia, Arya Pradipta, dan Ellen Cecilia. 2019. Earnings Management: ESOP and Corporate Governance. Academy of Accounting and Financial Studies Journal, 23(Sp.1), 1-13

Suwanti, Sri dan Wahidahwati. 2017. Pengaruh Good corporate governance, free cash flow, Manajemen Inventory dan Leverage terhadap Manajemen Laba. Jurnal IImu dan Riset Akuntansi, 6(9), 1-21.

Tiswiyanti, Wiwik, Dewi Fitriyani, dan Wiralestari. 2012. Analisis Pengaruh Komisaris Independen, Komite Audit, dan Kepemilikan Institusional terhadap Manajemen Laba. Jurnal Penelitian Universitas Jambi Seri Humaniora. 14(1), 61-66.

Upayarto, Budi. 2013. Pengaruh Financial Leverage, Ukuran Perusahaan, dan Independensi Komite Audit terhadap Manajemen Laba (Studi pada Perusahaan yang Termasuk dalam Jakarta Islamic Index (JII) Periode Tahun 2004-2007 di BEI). Jurnal Indonesia Membangun Sarana Informasi Akuntansi, Manajemen dan Perbankan, Vol. Januari-April 2013: 1-30.

Utari, Ni Putu Linda Ayu dan Maria M. Ratna Sari. 2016. Pengaruh Asimetri Informasi, Leverage, Kepemilikan Manajerial dan Kepemilikan Institusional pada Manajemen Laba. E-Jurnal Akuntansi Universitas Udayana, 15(3), 1886-1914.

Wiyadi, Rina Trisnawati, Noer Sasongko, dan Ichwani Fauzi. 2015. The Effect of Information Asymmetry, Firm Size, Leverage, Profitability, and Employee Stock Ownership on Earnings Management with Accrual Model. International Journal of Business, Economics, and Law, 8(2), 21-30.

Yogi, Luh Made Dwi Parama dan I Gusti Ayu Eka Damayanthi. 2016. Pengaruh Arus Kas Bebas, Capital Adequacy Ratio dan Good corporate governance pada Manajemen Laba. E-Jurnal Akuntansi Universitas Udayana, 15(2), 1056-1085.

Yudy dan Susanto, Yulius Kurnia. 2018. Kebijakan Hutang, Tata Kelola Perusahaan dan Manajemen Laba Akrual. Equity, 21(2), 107-115.

Yuliana, Agustin dan Ita Trisnawati. 2015. Pengaruh Auditor dan Rasio Keuangan terhadap Manajemen Laba. Jurnal Bisnis dan Akuntansi, 17(1), 33-45. 